752 Div

NBSIR 79-1588

\title{
Interlaboratory Evaluation of the Attic Floor Radiant Panel Test and Smoldering Combustion Test for Cellulose Thermal Insulation
}

J. Randall Lawson

Center for Fire Research

National Engineering Laboratory

National Bureau of Standards

Washington, D.C. 20234

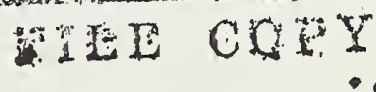

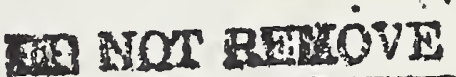

\section{February 1979}

Final Report

Prepared for:

Consumer Product Safety Commission Textile and Mechanical Engineering Group Bethesda, Maryland 20202 



\section{INTERLABORATORY EVALUATION OF}

THE ATTIC FLOOR RADIANT PANEL

TEST AND SMOLDERING

COMBUSTION TEST FOR CELLULOSE

THERMAL INSULATION

\section{J. Randall Lawson}

Center for Fire Research

National Engineering Laboratory

National Bureau of Standards

Washington, D.C. 20234

February 1979

Final Report

\section{Prepared for:}

Consumer Product Safety Commission

Textile and Mechanical Engineering Group

Bethesda, Maryland 20202

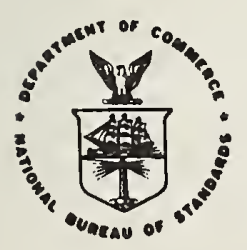

U.S. DEPARTMENT OF COMMERCE, Juanita M. Kreps, Secretary Jordan J. Baruch. Assistant Secretary for Science and Technology

NATIONAL BUREAU OF STANDARDS, Ernest Ambler, Director 

Page

LIST OF FIGURES • . . . . . . . . . . . . . . . . . . . . . . . iv LIST OF TABLES . . . . . . . . . . . . . . . . . . . . . . iv Abstract . . . . . . . . . . . . . . . . . . . . . . . 1

1. INTRODUCTION . . . . . . . . . . . . . . . . . . . . 2

2. TEST APPARATUS AND METHODS . . . . . . . . . . . . . . . . . . 3

2.1 Attic Floor Radiant Panel . . . . . . . . . . . . . . . 3

2.2 Smoldering Combustion..................... . . . . 3

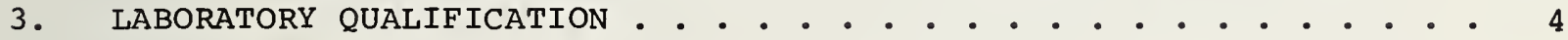

4. PARTICIPANTS . . . . . . . . . . . . . . . . . . . . . 5

5. MATERIALS AND SAMPLE PREPARATION . . . . . . . . . . . . . . . 5

6. EXPERIMENTAL DESIGN •. . . . . . . . . . . . . . . . . 6

7. TEST RESULTS AND DISCUSSION . . . . . . . . . . . . . . . . 7

7.1 Critical Radiant Flux Test . . . . . . . . . . . . . . 7

7.2 Smoldering Combustion Test . . . . . . . . . . . . . 9

8. SUMMARY AND CONCLUSIONS . . . . . . . . . . . . . . . . 10

9. RECOMMENDATIONS . . . . . . . . . . . . . . . . . . . 10

10. ACKNOWLEDGMENTS . . . . . . . . . . . . . . . . . . 11

11. REFERENCES . . . . . . . . . . . . . . . . . . . . . . . 11

APPENDIX A - PARTICIPANTS IN THE INTERLABORATORY FIRE TEST PROGRAM • • A-1 APPENDIX B - STATISTICAL METHODS . . . . . . . . . . . . . . . B-1

APPENDIX C - CELL AVERAGES AND STANDARD DEVIATIONS FOR CRITICAL RADIANT FLUX AND SMOLDERING COMBUSTION . . . . C-1 
Figure 1. Attic floor radiant panel tester schematic -

side evaluation ... . . . . . . . . . . . . . 12

Figure 2. Standard radiant heat energy flux profile . . . . . . . 13

Figure 3. Commercially built attic floor radiant panel . . . . . . 14

Figure 4. Home built attic floor radiant panel . . . . . . . . . 15

Figure 5. Smoldering combustion test (materials before testing) • • 16

Figure 6. Smoldering combustion test (materials after testing) • • 17

\section{LIST OF TABLES}

Page

Table 1. Critical radiant flux data . . . . . . . . . . . . 18

Table 2. Pass and fail tabulation (critical radiant flux) by

materials and laboratories ............. . . 19

Table 3. Precision estimates of critical radiant flux measurements $\quad 20$

Table 4. Comparison of precision estimates for fire test methods . . 21

Table 5. Percent weight loss - smoldering combustion test . . . . . 22

Table 6. Pass and fail tabulation (smoldering combustion) by materials and laboratories..... . . . . . . . . 23

Table 7. Precision estimates of percent weight loss (smoldering combustion) for materials without split test results . . . 24 


\section{J. Randall Lawson}

Abstract

An interlaboratory test program was conducted to provide estimates of repeatability and reproducibility of fire tests for cellulose loose fill insulation. The test methods evaluated were for critical radiant flux, using the Attic Floor Radiant Panel, and for smoldering combustion; they were based on Federal specification HH-I-515D. Seven commercially manufactured cellulose thermal insulations marketed for residential use were evaluated by each procedure. An additional set of four replicate hardboard specimens were tested by each participant using the Attic Floor Radiant Panel. Nine laboratories conducted the Attic Floor Radiant Panel test, and ten conducted tests for smoldering combustion. The testing was conducted during the month of June 1978. The participating laboratories were surveyed prior to testing in order to ensure conformance to the critical details of the test apparatus and procedures.

The between-laboratory coefficient of variation for critical radiant flux ranged from 13 to 30 percent with an average for seven insulation materials of 21 percent. Estimated precision levels of repeatability and reproducibility for the Attic Floor Radiant Panel test when compared to other standard flame spread tests and materials are favorable. Data from the Smoldering Combustion test was evaluated on a pass/fail basis with agreement by nine of ten laboratories for six of the seven materials tested. Seven of ten laboratories also agreed on the seventh material.

Based on work of this study, there is reasonable assurance that results from different laboratories evaluating the same material for compliance with Federal Specification HH-I-515D will be consistent. 
Key words: Attic floor radiant panel; cellulose thermal insulation; critical radiant flux; flame spread; test methods; smoldering combustion.

\section{INTRODUCTION}

Loose fill cellulose thermal insulation has been manufactured and used in the United States for several decades. With the increasing need to respond to the demand for energy conservation through reducing residential heat losses, the industry has grown at a rapid rate. With this growth, several problems have become apparent. As stated at the Consumer Product Safety Commission's (CPSC) public meeting of August 22, 1977, some of these problems were related to the fire properties of the materials. Only one fire test method has been used by regulatory bodies to evaluate the fire properties of cellulose insulation. This is the ASTM E 84 steiner Tunnel Test [1] ${ }^{1}$. It is apparent that the test is not designed for evaluating attic insulations since insulation is generally exposed on an attic floor and the tunnel test evaluates it on the ceiling. Additionally, the insulation sample must be supported by a fine mesh screen wire which further alters the natural environment. It was also recognized that the procedure did not take into account the smoldering combustion process. A separate test method was developed for the evaluation of this fire property. These problems with fire testing and the fire incidence noted in Denver, Colorado and other areas resulted in the updating of performance specifications for insulation.

The investigation of thermal insulation-related fires identified a significant fire scenario which had not been addressed. It was found that many insulation-related fires were initiated by the overheating of recessed light fixtures covered with insulation. The initial mode of combustion was a slowly propagating smoldering of the insulation. In some cases the smoldering material would involve other building materials and open flaming would occur. A review of fire scenarios and laboratory mockup tests on insulations showed that relatively rapid flame spread on the exposed surface of attic insulation could also be caused by ignition from open flaming sources [2]. As a result, a new standard was written, Federal specification HH-I-515D which replaced HH-I-515C, and new test methods were included to evaluate the fire properties of the materials [3]. The Attic Floor Radiant Panel test is an adaptation of an established test method for flooring

\footnotetext{
Numbers in brackets refer to the literature references listed at the end of this paper.
} 
materials $[4,5]$. The Smoldering Combustion test is a newly developed test for evaluating the tendency of thermal insulation to initiate and propagate a smoldering reaction.

As part of the test development, an interlaboratory test program was conducted to evaluate the repeatability ${ }^{2}$ and reproducibility ${ }^{3}$ of the critical Radiant Flux and Smoldering Combustion tests for cellulose thermal insulation materials.

\section{TEST APPARATUS AND METHODS}

\subsection{Attic Floor Radiant Panel}

Briefly, the basic elements of the test apparatus are a horizontallymounted $100 \mathrm{~cm}$ long specimen tray which receives radiant energy from an airgas fueled radiant panel mounted above the specimen and inclined at an angle of $30^{\circ}$ (see figure 1). A pilot burner is used to initiate the test by open flame ignition of the specimen. The gas panel generates a flux profile along the length of the specimen ranging from a maximum of $1.1 \mathrm{~W} / \mathrm{cm}^{2}$ to $0.1 \mathrm{~W} / \mathrm{cm}^{2}$ minimum [4]. The standard flux profile is shown in figure 2.

After the test chamber has been preheated to equilibrium conditions, the specimen is placed into test position and the chamber is closed. Following a two-minute preheat, the ignition flame is applied to the end of the specimen located under the radiant panel. The test is continued until the specimen flaming goes out (extinguishment). The distance burned to the point of extinguishment is converted to $\mathrm{W} / \mathrm{cm}^{2}$ from the calibrated flux profile graph and the result is reported as a critical radiant flux, $W / \mathrm{cm}^{2}[4]$. For a material to pass the test, the critical radiant flux must be equal to or greater than $0.12 \mathrm{~W} / \mathrm{cm}^{2} \quad[3]$.

\subsection{Smoldering Combustion}

The specimen holder is an open-top $20 \mathrm{~cm}$ square stainless steel box which is $10 \mathrm{~cm}$ high. During the test the specimen holder rests upon a glass fiberboard pad which is approximately $2.5 \mathrm{~cm}$ thick (see figure 5). The ignition source is a cigarette without a filter tip which is $85 \mathrm{~mm}$ long.

\footnotetext{
${ }^{2}$ Repeatability precision - repeatability or within-laboratory precision is defined in terms of the variability between test results obtained in the same laboratory on the same material [6].

3 Reproducibility precision - reproducibility or between-laboratory precision is defined in terms of the variability between test results obtained in different laboratories on the same material [6].
} 
The weight of material necessary to fill the holder at a settled density is determined. The specimen holder is filled to the top with the required amount of material. An $8 \mathrm{~mm}$ diameter vertical hole is made in the center of the material, and a well-lit cigarette is inserted in the formed cavity. The lit end of the cigarette is upward and flush with the sample surface. The cigarette and specimen are allowed to burn for at least two hours or until smoldering is no longer progressing. After the specimen holder has cooled down to $25^{\circ} \mathrm{C}$, the holder with its material residue is weighed and the weight loss is determined. For a material to pass, there must be no evidence of flaming combustion and the weight loss must be $\leq 15$ percent of the initial weight [3].

\section{LABORATORY QUALIFICATION}

Prior to initiating the round robin test program, Mr. David E. Swanson of the National Bureau of Standards visited a number of laboratories to check the operation of their radiant panel apparatus. Special attention was given to checking the calibration of the radiant flux meters and flux profiles. The following is a discussion of the survey findings.

The calibration of the radiant flux meters, used for adjusting the radiant flux profile for the test, was compared to that of an NBS calibrated flux meter. Out of eleven laboratories checked, one was found to be using an incorrect flux meter calibration value. A correct calibration constant was provided for use by the laboratory. The laboratory survey indicated a general pattern of initial difficulties in adjusting the radiant panels for the specified radiant flux profile. In some of these laboratories, this may be attributed to the lack of experience with the apparatus because the units had been recently acquired, rather than an insufficient description of the test procedure. In order to correct this problem, adjustments were required on sample to panel distance, radiant panel angle, and gas and airflow rates. Gas and airflow rates were difficult to adjust on several test instruments. This was mainly due to the coarseness of the flow control valves. One panel was being operated without airflow control to the burner, relying only on the adjustment of gas flow for control. Another laboratory did not have the optical pyrometer used for standardizing the thermal output of the radiant panel. Several laboratories had experienced trouble with the temperatureactivated safety gas cut-off system on the panels. The thermocouples controlling the automatic shutdown were not located in the proper position. Sporadic cooling of these thermocouples resulted in the gas flow to the panels being cut off. These thermocouples were repositioned. The only other significant problem noted was associated with airflow through the test chamber. 
In one laboratory, the building exhaust duct was connected directly to the test chamber stack by a flexible hose. This induced an unusually large airflow through the test chamber which substantially lowered the chamber temperature and also affected the radiant flux profile. The flexible hose was removed allowing natural convection to remove the products of combustion, and the unit was recalibrated.

After the laboratory investigations were completed, the nine participants were selected for the test program. Of these, two had assembled the apparatus from drawings in the specification, and seven had commercially manufactured test apparatus. Of the commercial instruments, two manufacturers were represented. Figures 3 and 4 show representative examples of commercial and home-built test instruments that were used in this test program.

\section{PARTICIPANTS}

The laboratories who collaborated in this study are listed in appendix A. The degree of experience among laboratories in using the insulation test methods varied from one month to one year. Five of the participating laboratories provide commercial test services for the public while the others are government laboratories. In order to remain consistent with the usual practice in interlaboratory studies, the laboratories are identified in this report only by code letters. It should be noted that one laboratory conducted only the Smoldering Combustion test.

\section{MATERIALS AND SAMPLE PREPARATION}

Seven cellulose thermal insulation materials were obtained from manufacturers for the test program. The basic ingredient in six of the materials was ground waste paper while the seventh was cotton. The manufacturers indicated that all of the materials were treated with fire-retardant chemicals. The fire-retardant chemicals in one material were added through a wet process while the chemicals for the six other materials were added by mechanical dry blending. All of the materials were produced primarily for the home insulation market. The materials are typically installed by being blown into building spaces, attic floors and wall cavities by blowing machines. The materials were received in bags containing insulation whose nominal weights ranged from 9.1 to $18.2 \mathrm{~kg}$ (20 to $40 \mathrm{lbs})$. Before the insulation was separated into sample batches and blended, each product was given a code letter, A through $\mathrm{G}$, which was used throughout the program for identification. 
After the bags were weighed, each material used in the test program was removed from its original bag and mixed separately. Mixing was accomplished by blowing the insulation through $30.3 \mathrm{~m}(100 \mathrm{ft})$ of hose into a $1.8 \mathrm{~m}^{3}$ (65 $\mathrm{ft}^{3}$ ) blending chamber using a commercial blowing machine. Depending on the properties of the materials, two or three bags were fed through the blowing machine and into the mixing chamber before samples were taken from the lot. Samples weighing a nominal $4.5 \mathrm{~kg}$ (10 lbs) were bagged separately and code labeled for shipment to the participating laboratories. Before the bags were sealed, a $454 \mathrm{~g}$ (l lb) sample was taken from each. These samples were placed into a separate bag for each product and kept as a composite to be tested by NBS. After each lot was mixed, the mixing system was thoroughly cleaned before the next material was blended. When all the materials were bagged, they were placed into groups for shipment and lot numbers were recorded along with the laboratory identification number. The samples were then boxed with a set of four hardboard specimens and a four-pronged pick, which was used for fluffing the insulation, and shipped to the participants. For simplicity and consistency, slight modifications were made in a few procedures and uniform instructions were sent to the participants (see section 6).

\section{EXPERIMENTAL DESIGN}

Each laboratory participating in the test program received seven cellulose insulation materials and one set of four hardboard specimens. The fire test procedures used by the participants in this interlaboratory test program were slight modifications of tests found in Federal specification HH-I-515D [3]. The tests conducted were for Critical Radiant Flux (section 4.8.7 of HH-I-515D) and Smoldering Combustion (section 4.8.8 of HH-I-515D). Both tests were performed on each of the cellulosic insulation specimens. The hardboard specimens served as a reference material for Critical Radiant Flux method only.

In order to maintain consistency in the test evaluation, minor changes were made in the test procedures. It was requested that all laboratories test their specimens at a fixed density instead of the settled density called for in the specification. Tests on all insulation materials except $C$ were conducted at a nominal $48 \mathrm{~kg} / \mathrm{m}^{3}\left(3.0 \mathrm{lbs} / \mathrm{ft}^{3}\right)$ density with an allowable range between 46.5 and $49.7 \mathrm{~kg} / \mathrm{m}^{3}\left(2.9\right.$ and $\left.3.1 \mathrm{lbs} / \mathrm{ft}^{3}\right)$. Because the blown density of material $C$ was much less than the others, it was requested that tests be performed at a nominal density of $24 \mathrm{Kg} / \mathrm{m}^{3}\left(1.5 \mathrm{lbs} / \mathrm{ft}^{3}\right)$ with a range from 22.4 to $25.6 \mathrm{~kg} / \mathrm{m}^{3}\left(1.4\right.$ to $\left.1.6 \mathrm{lbs} / \mathrm{ft}^{3}\right)$. 
Specimen preparation also varied somewhat from the procedure called for in the specification. It was found that repeated passes of cellulose insulation through a blowing machine results in damage to the cellulose fiber and alteration of its properties. Since the materials had already been blown through a commercial insulation blowing machine when they were blended at NBS, it was requested that the test specimens be prepared by hand, filling the test containers to the weight required for the specified densities. Care was to be taken to break up any lumps and to fluff the material using the pick until the specimens evenly filled the test container.

The conditioning procedure for the smoldering Combustion test was also altered to conform with the procedure required for the Critical Radiant Flux test. All materials and cigarettes were to be conditioned for a minimum of 48 hours in an environment of $21 \pm 3^{\circ} \mathrm{C}\left(69.8 \pm 5.4^{\circ} \mathrm{F}\right)$ and $50 \% \mathrm{R} . \mathrm{H}$. before testing.

\section{TEST RESULTS AND DISCUSSION}

Nine laboratories conducted tests and provided data on the Critical Radiant Flux test. Ten laboratories conducted smoldering Combustion tests and supplied data. The data were compiled and compared with the requirements set forth in the Federal Specification HH-I-515D. The specification states in paragraph 3.1.9 that for a material to pass, the critical radiant flux shall be equal to or greater than $0.12 \mathrm{~W} / \mathrm{cm}^{2}$. For smoldering combustion, paragraph 3.1 .10 states that a material must show no evidence of flaming combustion and must have a weight loss $\leq 15$ percent of the initial weight in order to be accepted.

\section{I Critical Radiant Flux Test}

Three tests were conducted by each laboratory on each cellulose insulation material; four hardboard specimens were also tested. Since loose fill cellulose insulation and its properties are known to be variable, the use of a fairly uniform hardboard sheet, which has been used in other testing programs, was included to provide a reference measure of test repeatability and reproducibility. Table 1 lists the test results for critical radiant flux provided by each laboratory.

Material D experienced five individual tests in two laboratories where the specimen did not ignite; eight laboratories reported data for materials $B$ and $F$ in which some or all of the specimens burned the entire length. The results contained in these ten data cells were not included in the statistical 
treatment. Two hardboard tests from laboratory number 2 were excluded from analysis also because the laboratory indicated that the radiant panel extinguished while the tests were in progress.

Table 2 shows the Critical Radiant Flux test results ordered from pass to fail tabulation. Material B failed in seven of the the nine laboratories and exhibited relatively low critical radiant flux values in the laboratories where it passed (see table 1). Materials $\mathrm{E}$ and $\mathrm{F}$ experienced failures in one and two laboratories, respectively. In summary, the results of four materials had full agreement in all nine laboratories. The results of one material agreed in eight of nine laboratories, and the results of two materials agreed in seven of nine laboratories.

Table 3 exhibits the results of a statistical evaluation which provides information related to the precision of the critical Radiant Flux test. The test results were evaluated using statistical methods found in the "Tentative Recommended Practice for Conducting an Interlaboratory Test Program to Determine the Precision of Test Methods" being prepared by ASTM Committee E 11 [6]. A brief presentation of the statistical methods used in this report is given in appendix $B$. The table presents the overall laboratory average for critical radiant flux, pooled repeatability standard deviation, reproducibility standard deviation and the coefficients of variation for repeatability and reproducibility. (See appendix C for cell averages and standard deviations.) Although material $B$ exhibited the best repeatability with a coefficient of variation of 7.7 percent, it should be noted that this value was calculated using the critical radiant flux results reported from only two laboratories. Material E exhibited the greatest coefficient of variation for repeatability with a value of 14.8 percent. The coefficient of variation for reproducibility ranged from 13 to 30 percent. The overall average coefficient of variation for repeatability for seven cellulose insulation materials was 12 percent; the average coefficient of variation for reproducibility between laboratories for seven materials was 21 percent. These values were fairly close to the values for the hardboard sheet material and also compare favorably with values for carpeting materials tested by the Floor Radiant Panel [4] and E 84 Flame spread tests [7] (see table 4). As shown, the range and median coefficients of variation of the Attic Floor Radiant Panel are reasonable when compared to similar estimates available for other test methods. Furthermore, it was expected that the precision estimates for loose fill cellulose would be somewhat higher than that for carpeting. Thus, the testing of loose fill cellulose insulation materials by this test method does not introduce exceptionally high levels of variability. Also, a comparison of hardboard test results from this interlaboratory program shows better reproducibility than that obtained from an 
uncontrolled program involving 21 laboratories using the Floor Radiant Panel test. An informal "calibration" experiment was carried out before an attempt was made to standardize various test parameters. This work was done in order to determine the extent of between-laboratory variability. (The results of the calibration experiment resulted in a tightening of the test procedure.) The data show that the average critical radiant flux obtained for hardboard in the present program was $0.20 \mathrm{~W} / \mathrm{cm}^{2}$ and the earlier calibration experiment was $0.19 \mathrm{~W} / \mathrm{cm}^{2}$. The repeatability coefficient of variation for hardboard in this project was 12.7 with a reproducibility coefficient of variation of 19.5 (see table 3). The repeatability coefficient of variation for the hardboard in the uncontrolled calibration experiment was 13.1 with a reproducibility coefficient of variation of 91.5 .

\subsection{Smoldering Combustion Test}

Ten laboratories supplied Smoldering Combustion test data. Each cel1 4 consisted of three determinations as required by Federal specification HH-I-515D. Table 6 shows a tabulation of percent weight loss of the test specimens as reported by the laboratories. Because of the split test results, some pass and some fail, noted in a number of data cells exhibited in table 5 , calculations of repeatability and reproducibility were made for only three materials.

Figures 5 and 6 show examples of materials prepared for testing and the specimens two hours after the cigarettes were ignited. It is evident that where smoldering combustion was initiated and propagated readily a significant weight loss occurred; where it was not initiated the weight loss was very small. The chemical composition of the sample and the extent of separation of the fire-retardant chemicals are principal determining factors in the propagation of smoldering combustion.

Three laboratories experienced split test results within a single set of tests. This can be seen in table 5 and is noted in table 6 by the asterisks. There were six cells with split results out of a total of 70 cells. Four materials experienced this phenomenon, C, E, F and G; materials $E$ and $F$ show split results in two different laboratories. Material E exhibited the greatest inconsistency, passing in three laboratories and failing in seven. Within the seven failing laboratories two data cells show passing results. This variation appears to be directly related to the physical separation of fireretardant chemicals from the ground paper. A deposit of granular chemicals

$\overline{{ }^{4} \text { Cell - each of }} \mathrm{p}$ laboratories makes measurements on each of $q$ materials. This gives rise to $p \times q$ "cells". Each cell consists of $n$ measurements [6]. 
was observed in the bottom of sample bags containing material E. Materials $F$ and $G$ failed in nine of the ten laboratories with $F$ exhibiting split results in two data cells and $G$ with split results in one. Materials $B$ and $D$ were failures in all laboratories. Material C exhibited two failures in one data cell and passed in the remaining nine. For statistical data on materials without split results, see table 7 .

Further analysis of table 6 provides some information associated with reproducibility. Agreement among the laboratories was relatively good. The results of three materials had full agreement in all ten laboratories. The results of three materials agreed in nine of ten laboratories and the results of one material had agreement in seven of the ten laboratories. It appears that some variation in laboratory operations contributed to the scatter of data.

\section{SUMMARY AND CONCLUSIONS}

An interlaboratory program was carried out to determine the repeatability and reproducibility of the critical Radiant Flux and Smoldering Combustion tests referenced in Federal Specification HH-I-515D. Seven cellulose thermal insulation products were evaluated in ten laboratories. The results indicate that the estimated precision levels of repeatability and reproducibility for the Attic Floor Radiant Panel test were not significantly greater for loose fill cellulose materials than for other materials, and compare favcrably with precision estimates available from other standard fire test methods. Physical separation of chemical fire-retardants was quite noticeable in one of the seven materials and the likely cause of variability noted in the test results, particularly for the Smoldering Combustion test. Based on the work of this study, there is reasonable assurance that results from different laboratories evaluating the same material for compliance with Federal specification HH-I-515D will be consistent.

\section{RECOMMENDATIONS}

In view of the variation experienced with the Smoldering Combustion test, it would be appropriate to further study the possibilities of improving the test procedure. 
Appreciation is extended to the manufacturers who freely provided materials for this test program and the participating laboratories who conducted the testing without compensation. Mr. Bernard Schwartz of the Consumer Product Safety Commission and the field offices assisted in obtaining the test materials. Statistical consultation was provided by Mrs. Mary G. Natrella, Statistical Engineering Division, National Bureau of Standards. Appreciation is also extended to $\mathrm{Mr}$. Sanford Davis, Furnishings Flammability Research, National Bureau of Standards, who provided assistance through the test program, and to Mr. David E. Swanson for conducting the laboratory survey.

\section{REFERENCES}

[1] Standard Test Method for Surface Burning Characteristics of Building Materials, ASTM E 84-77, American Society for Testing and Materials, Philadelphia, Pa. (1977).

[2] Gross, D., A preliminary study of the fire safety of thermal insulation for use in attic or enclosed spaces in residential housing, Nat. Bur. Stand. (U.S.), NBSIR 78-1497 (1978).

[3] Insulation Thermal (Loose Fill for Pneumatic or Poured Application): Cellulosic or Wood Fiber, Federal Specification HH-I-515D (June 15, 1978).

[4] Benjamin, I. A. and Adams, C. H., Proposed criteria for use of the critical radiant flux test method, Nat. Bur. Stand. (U.S.), NBSIR 75-950 (Dec. 1975).

[5] Standard Method of Test for Critical Radiant Flux for Floor Covering Systems Using a Radiant Heat Energy Source, NFPA 253, National Fire Protection Association, Boston, Mass. (1978).

[6] Tentative Recommended Practice for Conducting an Interlaboratory Test Program to Determine the Precision of Test Methods, ASTM Committee E II, American Society for Testing and Materials, Philadelphia, Pa. (1978).

[7] Lee, T. G. and Huggett, Clayton, Interlaboratory Evaluation of ASTM E 84-70, Tunnel Test Applied to Floor Coverings, Journal of Testing and Evaluation, Vol. 3, No. 1, American Society for Testing and Materials, Philadelphia, Pa. (1975). 


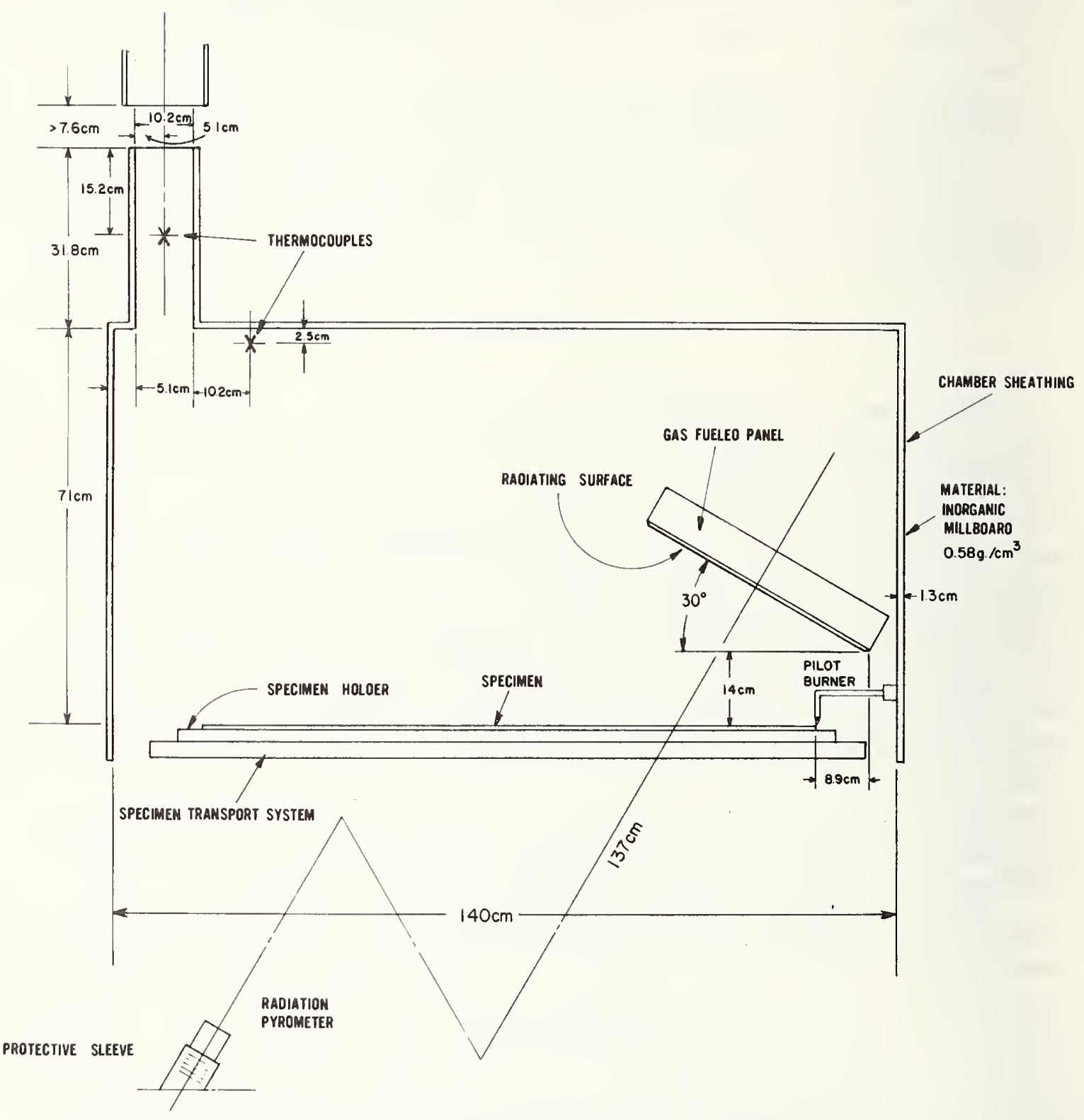

Figure 1. Attic floor radiant panel tester schematic side evaluation 


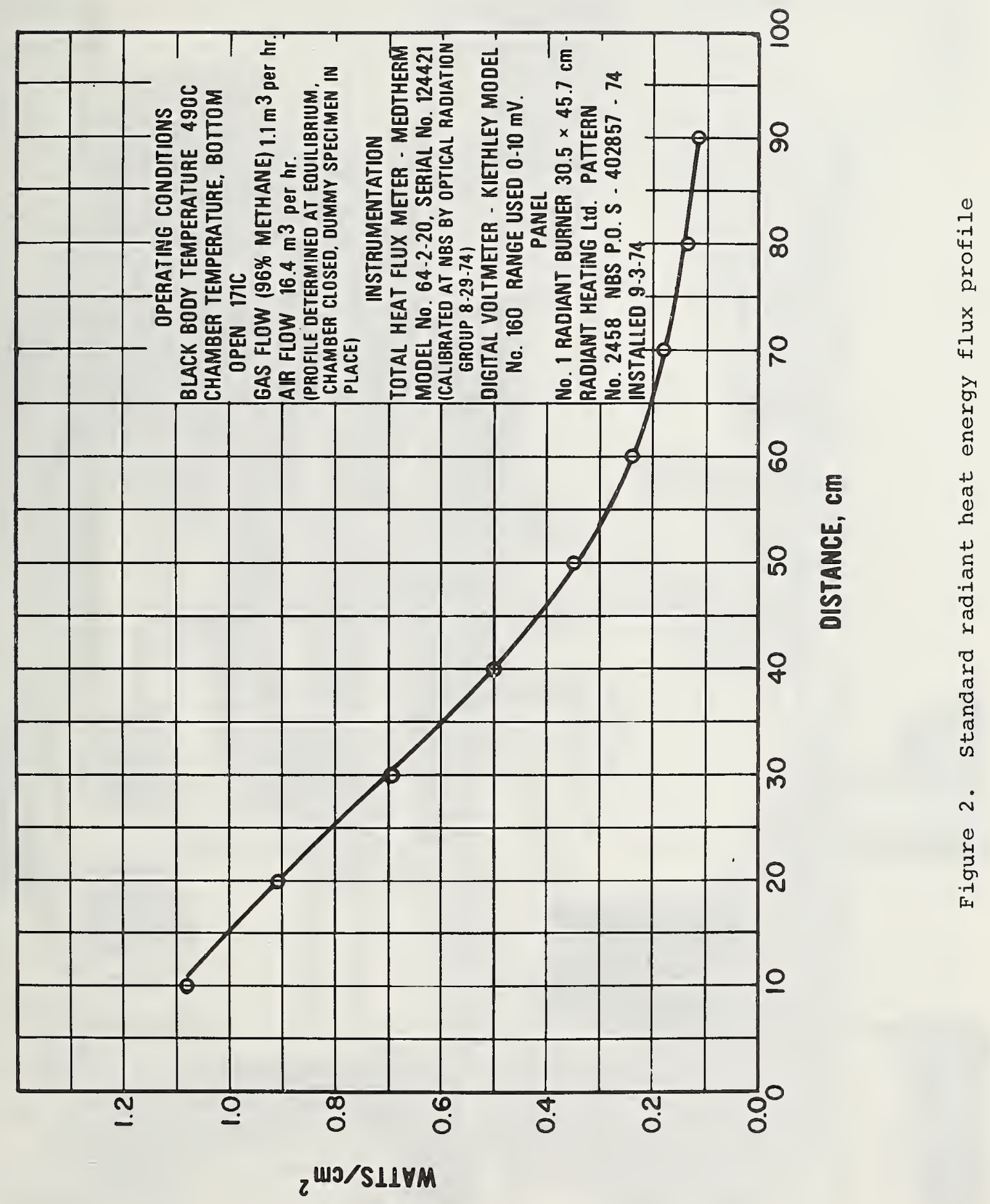




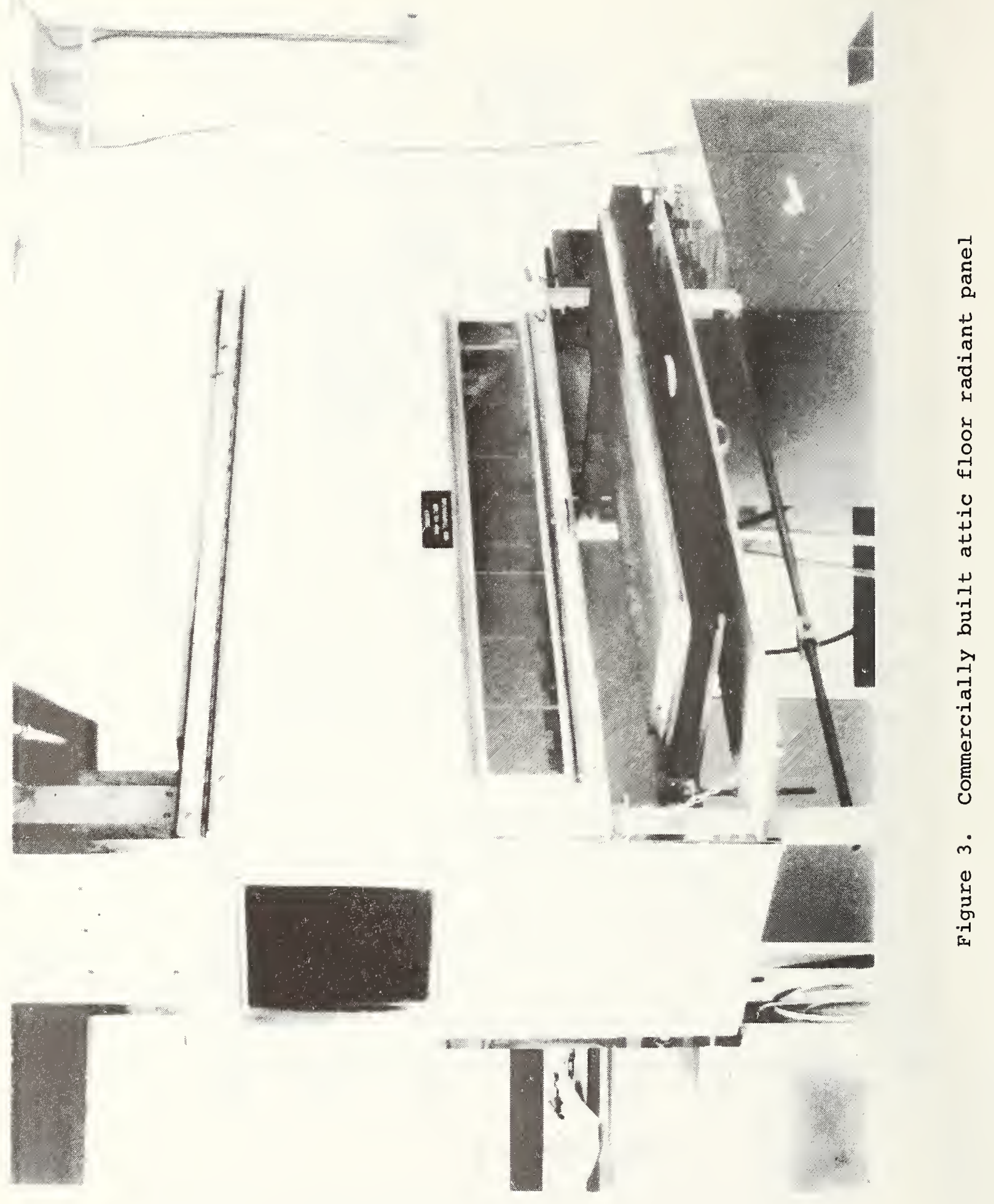




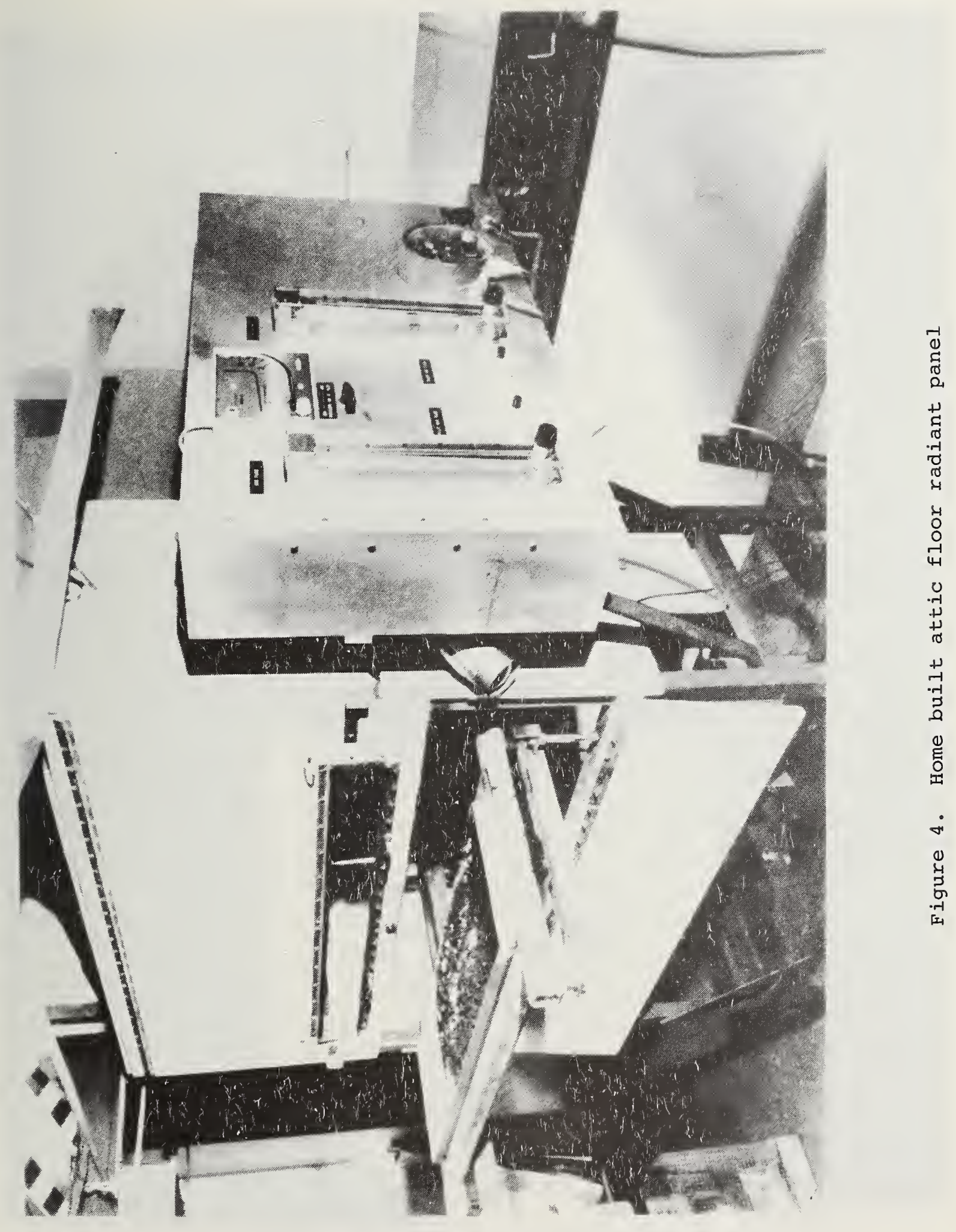




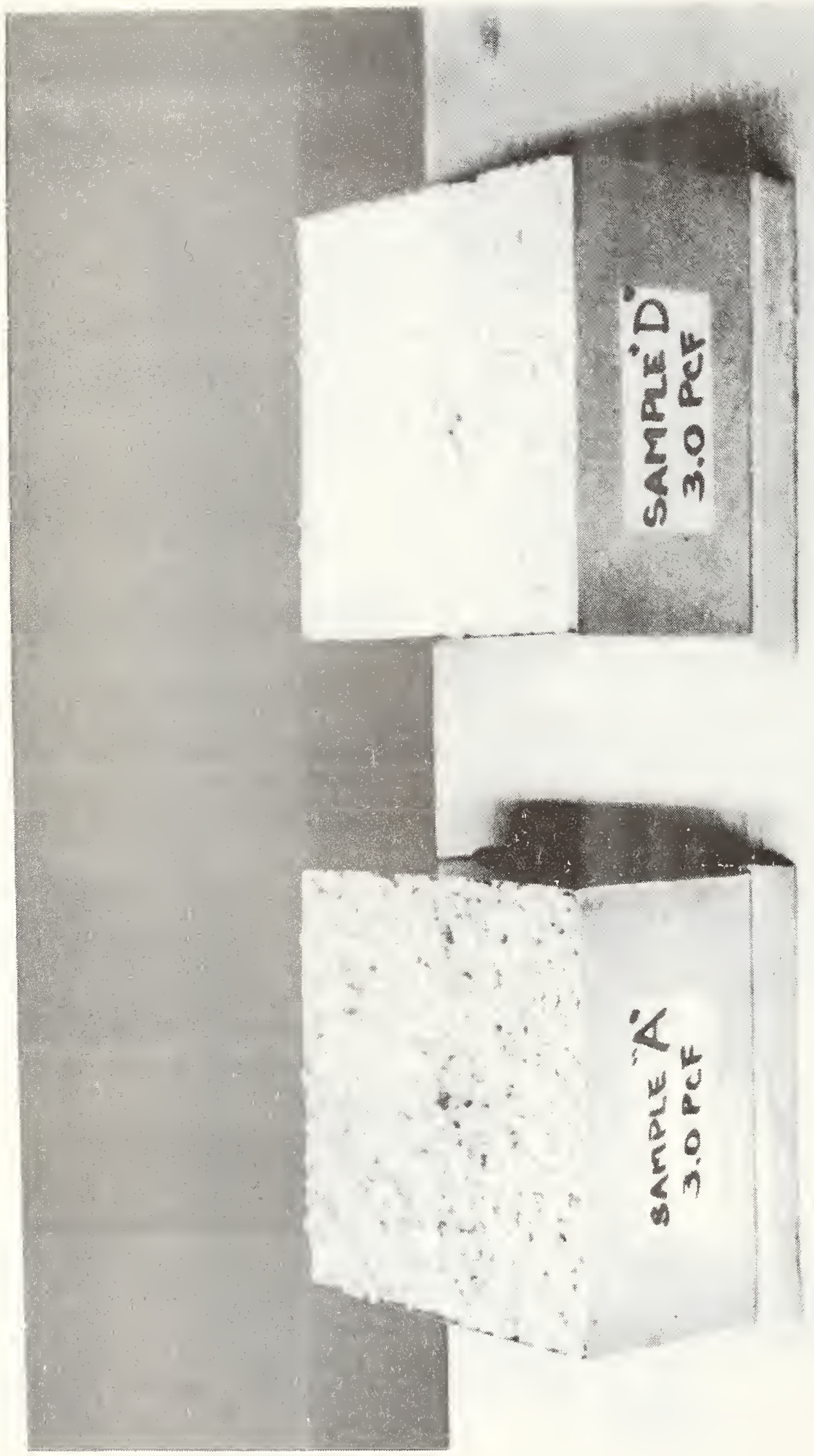

o

ثू

告

in

I

द्

I

है

ت્.

เก

(1)

尜 

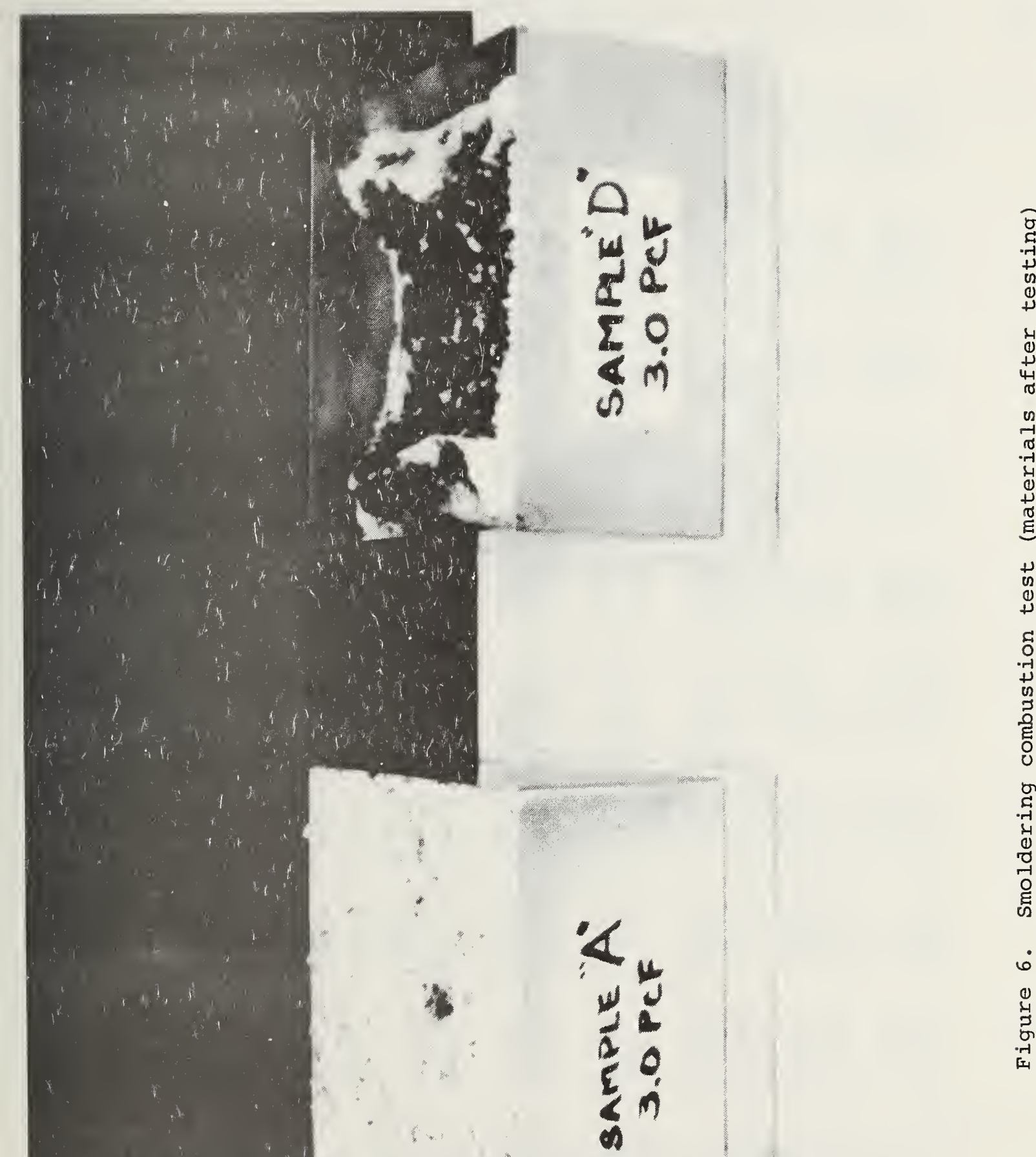


\section{Material}

\begin{tabular}{|c|c|c|c|c|c|c|c|c|}
\hline & A & B & C & D & $\mathrm{E}$ & F & G & Hardboarc \\
\hline 1 & $\begin{array}{l}0.19 \\
0.20 \\
0.18\end{array}$ & $\begin{array}{l}<0.11^{a} \\
<0.11 \\
<0.11\end{array}$ & $\begin{array}{l}0.16 \\
0.18 \\
0.20\end{array}$ & $\begin{array}{l}0.51 \\
0.39 \\
0.41\end{array}$ & $\begin{array}{l}0.10 \\
0.11 \\
0.12\end{array}$ & $\begin{array}{l}0.14 \\
0.15 \\
0.13\end{array}$ & $\begin{array}{l}0.15 \\
0.16 \\
0.15\end{array}$ & $\begin{array}{l}0.21 \\
0.19 \\
0.23 \\
0.19\end{array}$ \\
\hline 2 & $\begin{array}{l}0.24 \\
0.25 \\
0.22\end{array}$ & $\begin{array}{r}<0.11^{\mathrm{a}} \\
0.12 \\
<0.11\end{array}$ & $\begin{array}{l}0.20 \\
0.21 \\
0.19\end{array}$ & $\begin{array}{l}0.49 \\
0.49 \\
0.53\end{array}$ & $\begin{array}{l}0.18 \\
0.17 \\
0.19\end{array}$ & $\begin{array}{l}0.21 \\
0.18 \\
0.16\end{array}$ & $\begin{array}{l}0.26 \\
0.24 \\
0.25\end{array}$ & $\begin{array}{c}c \\
c \\
0.22 \\
0.21\end{array}$ \\
\hline 3 & $\begin{array}{l}0.29 \\
0.24 \\
0.34\end{array}$ & $\begin{array}{l}0.14 \\
0.15 \\
0.17\end{array}$ & $\begin{array}{l}0.25 \\
0.27 \\
0.28\end{array}$ & $\begin{array}{l}0.46 \\
0.41 \\
0.46\end{array}$ & $\begin{array}{l}0.21 \\
0.20 \\
0.21\end{array}$ & $\begin{array}{l}0.16 \\
0.18 \\
0.15\end{array}$ & $\begin{array}{l}0.38 \\
0.35 \\
0.41\end{array}$ & $\begin{array}{l}0.17 \\
0.15 \\
0.14 \\
0.13\end{array}$ \\
\hline 4 & $\begin{array}{l}0.18 \\
0.19 \\
0.22\end{array}$ & $\begin{array}{l}<0.11^{\mathrm{a}} \\
<0.11 \\
<0.11\end{array}$ & $\begin{array}{l}0.16 \\
0.14 \\
0.13\end{array}$ & $\begin{array}{l}\text { DNI } \\
\text { DNI } \\
\text { DNI }\end{array}$ & $\begin{array}{l}0.18 \\
0.14 \\
0.15\end{array}$ & $\begin{array}{r}<0.11^{a} \\
0.11 \\
<0.11\end{array}$ & $\begin{array}{l}0.21 \\
0.19 \\
0.19\end{array}$ & $\begin{array}{l}0.22 \\
0.22 \\
0.22 \\
0.23\end{array}$ \\
\hline 5 & $\begin{array}{l}0.23 \\
0.25 \\
0.24\end{array}$ & $\begin{array}{l}<0.11^{a} \\
<0.11 \\
<0.11\end{array}$ & $\begin{array}{l}0.27 \\
0.28 \\
0.30\end{array}$ & $\begin{array}{l}0.39 \\
0.45 \\
0.41\end{array}$ & $\begin{array}{l}0.13 \\
0.15 \\
0.15\end{array}$ & $\begin{array}{l}0.14 \\
0.13 \\
0.12\end{array}$ & $\begin{array}{l}0.25 \\
0.22 \\
0.19\end{array}$ & $\begin{array}{l}0.21 \\
0.22 \\
0.15 \\
0.12\end{array}$ \\
\hline 6 & $\begin{array}{l}0.21 \\
0.12 \\
0.16\end{array}$ & $\begin{aligned} & 0.11^{\mathrm{a}} \\
& 0.11 \\
&<0.11\end{aligned}$ & $\begin{array}{l}0.26 \\
0.21 \\
0.24\end{array}$ & $\begin{array}{l}0.55 \mathrm{~b} \\
\mathrm{DNI} \\
\mathrm{DNI}\end{array}$ & $\begin{array}{l}0.17 \\
0.15 \\
0.12\end{array}$ & $\begin{array}{l}0.13 \\
0.16 \\
0.14\end{array}$ & $\begin{array}{l}0.24 \\
0.20 \\
0.24\end{array}$ & $\begin{array}{l}0.21 \\
0.22 \\
0.20 \\
0.25\end{array}$ \\
\hline 7 & $\begin{array}{l}0.20 \\
0.23 \\
0.20\end{array}$ & $\begin{array}{l}0.13 \\
0.13 \\
0.13\end{array}$ & $\begin{array}{l}0.32 \\
0.31 \\
0.31\end{array}$ & $\begin{array}{l}0.62 \\
0.49 \\
0.44\end{array}$ & $\begin{array}{l}0.17 \\
0.21 \\
0.22\end{array}$ & $\begin{array}{l}0.12 \\
0.19 \\
0.13\end{array}$ & $\begin{array}{l}0.27 \\
0.37 \\
0.26\end{array}$ & $\begin{array}{l}0.23 \\
0.23 \\
0.23 \\
0.21\end{array}$ \\
\hline 8 & $\begin{array}{l}0.27 \\
0.27 \\
0.27\end{array}$ & $\begin{array}{l}<0.12^{\mathrm{a}} \\
<0.12 \\
<0.12\end{array}$ & $\begin{array}{l}0.22 \\
0.28 \\
0.25\end{array}$ & $\begin{array}{l}0.55 \\
0.54 \\
0.53\end{array}$ & $\begin{array}{l}0.27 \\
0.18 \\
0.18\end{array}$ & $\begin{aligned} & 0.14 \\
< & 0.12 \\
< & 0.12\end{aligned}$ & $\begin{array}{l}0.21 \\
0.22 \\
0.21\end{array}$ & $\begin{array}{l}0.22 \\
0.25 \\
0.27 \\
0.28\end{array}$ \\
\hline 9 & $\begin{array}{l}0.18 \\
0.20 \\
0.17\end{array}$ & $\begin{array}{l}0.10 \\
0.10 \\
0.10\end{array}$ & $\begin{array}{l}0.18 \\
0.20 \\
0.24\end{array}$ & $\begin{array}{l}0.60 \\
0.43 \\
0.40\end{array}$ & $\begin{array}{l}0.20 \\
0.16 \\
0.16\end{array}$ & $\begin{array}{l}0.16 \\
0.17 \\
0.14\end{array}$ & $\begin{array}{l}0.18 \\
0.22 \\
0.18\end{array}$ & $\begin{array}{l}0.20 \\
0.17 \\
0.20 \\
0.12\end{array}$ \\
\hline
\end{tabular}

In the statistical treatment of the data, data cells containing values designated by the less than sign "<" were not included in the analysis.

$\mathrm{b}_{\text {DNI }}=$ did not ignite. These data cells were not included in the statistical treatment.

$\mathrm{C}_{\text {Two tests }}$ were not included because the radiant panel went out while the tests were in progress. 
Table 2. Pass and fail tabulation (critical radiant flux) by materials and laboratories

$\underline{\mathrm{Lab}}$

\begin{tabular}{|c|c|c|c|c|c|c|}
\hline & $\underline{\mathrm{D}}$ & $\underline{G}$ & $\underline{\mathrm{C}}$ & $\underline{A}$ & $\underline{\mathbf{E}}$ & $\underline{F}$ \\
\hline 1 & $P$ & $\mathrm{P}$ & $\mathrm{P}$ & $P$ & $\mathbf{F}$ & $\mathrm{P}$ \\
\hline 2 & $\mathrm{P}$ & $\mathrm{P}$ & $P$ & $\mathrm{P}$ & $\mathrm{P}$ & $\mathrm{P}$ \\
\hline 3 & $\mathrm{P}$ & $\mathrm{P}$ & $\mathrm{P}$ & $\mathrm{p}$ & P & P \\
\hline 4 & $\mathrm{P}$ & $\mathrm{P}$ & $\mathrm{P}$ & $P$ & $\mathrm{P}$ & $F$ \\
\hline 5 & $\mathrm{P}$ & $\mathrm{P}$ & $\mathrm{P}$ & $\mathrm{P}$ & $\mathrm{P}$ & $\mathrm{P}$ \\
\hline 6 & $\mathrm{P}$ & $\mathrm{P}$ & $\mathrm{P}$ & $\mathrm{P}$ & $\mathrm{P}$ & $\mathrm{P}$ \\
\hline 7 & $\mathrm{P}$ & $\mathrm{P}$ & $\mathrm{P}$ & $P$ & $\mathrm{P}$ & $\mathrm{P}$ \\
\hline 8 & $\mathrm{P}$ & $\mathrm{P}$ & $\mathrm{P}$ & $\mathrm{P}$ & $\mathrm{P}$ & $\mathbf{F}$ \\
\hline 9 & $\mathrm{P}$ & $\mathrm{P}$ & $P$ & $P$ & $\mathrm{P}$ & $P$ \\
\hline
\end{tabular}

No. of

Failures 0

0

0

1

2

7 


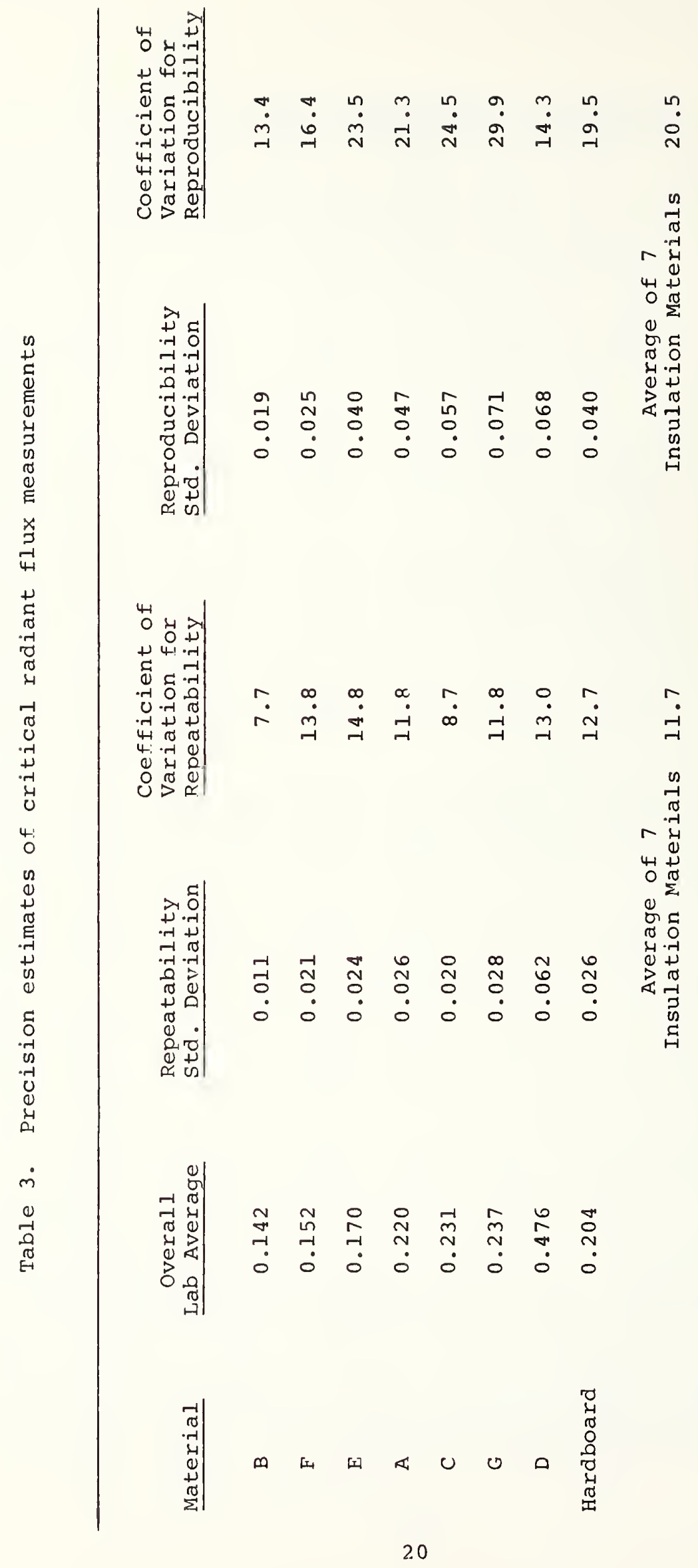




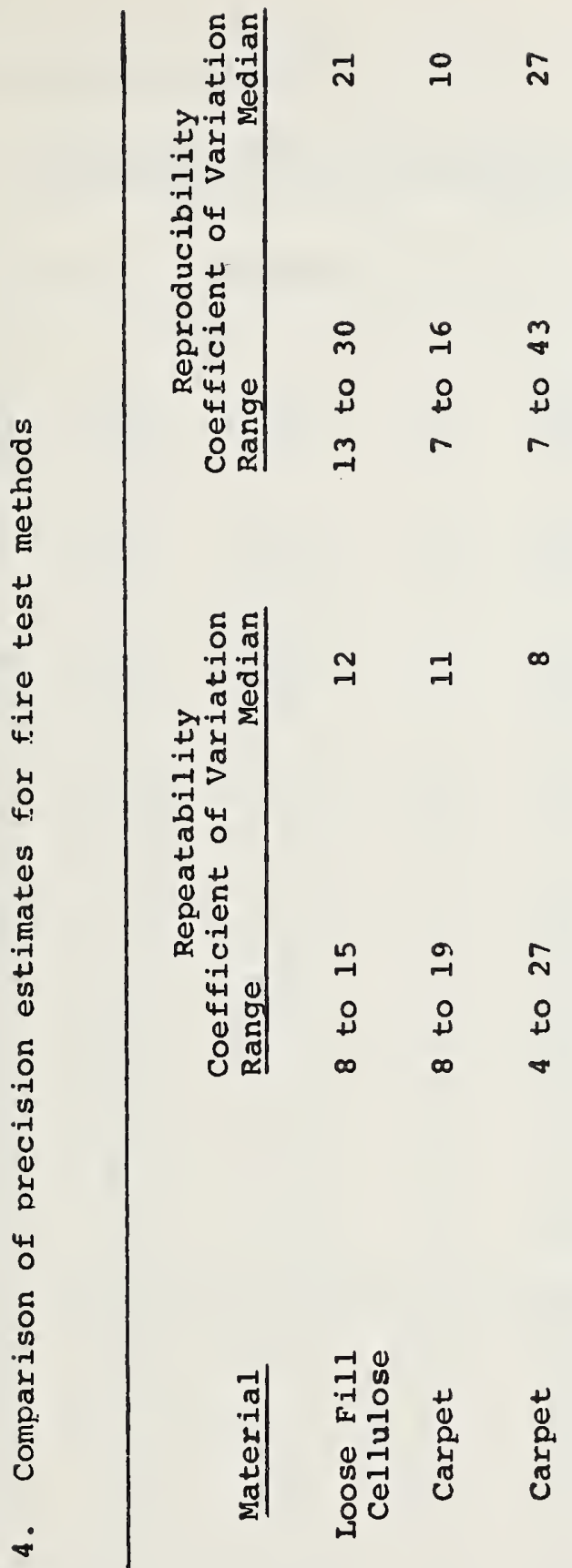

$$
\begin{aligned}
& \text { స్త }
\end{aligned}
$$


$\underline{\mathrm{Lab}}$

Material

\begin{tabular}{|c|c|c|c|c|c|c|c|}
\hline & A & B & C & D & $\mathrm{E}$ & F & G \\
\hline \multirow[t]{3}{*}{1} & 0.8 & 66.8 & 0.7 & 57.5 & 54.5 & 47.5 & 54.9 \\
\hline & 0.3 & 66.4 & 0.1 & 52.9 & 52.4 & 43.2 & 55.2 \\
\hline & 0.2 & 67.3 & 0.2 & 49.1 & 49.7 & 46.3 & 54.4 \\
\hline \multirow[t]{3}{*}{2} & 0.5 & 62.5 & -0.1 & 70.8 & 0.2 & 0.0 & 0.2 \\
\hline & 0.4 & 62.4 & -0.2 & 50.8 & 0.2 & 0.1 & 1.3 \\
\hline & 0.6 & 64.5 & -0.1 & 46.6 & 0.1 & 0.2 & 0.1 \\
\hline \multirow[t]{3}{*}{3} & 2.4 & 61.3 & 1.5 & 54.2 & -0.2 & 49.3 & 51.7 \\
\hline & 3.4 & 60.7 & 1.3 & 54.0 & -0.5 & 46.8 & 51.8 \\
\hline & 2.9 & 60.3 & 1.3 & 55.7 & 0.2 & 48.7 & 51.3 \\
\hline \multirow[t]{3}{*}{4} & 1.0 & 60.0 & 25.3 & 77.4 & 46.5 & 2.5 & 57.4 \\
\hline & 1.0 & 62.1 & 0.9 & 62.6 & 40.0 & 40.0 & 55.4 \\
\hline & 1.0 & 60.0 & 40.7 & 68.9 & 45.0 & 35.0 & 50.0 \\
\hline \multirow[t]{3}{*}{5} & 0.3 & 67.9 & 0.3 & 78.6 & 0.3 & 62.2 & 1.5 \\
\hline & 0.2 & 69.9 & 0.3 & 81.2 & 0.3 & 80.4 & 71.7 \\
\hline & 0.2 & 68.3 & 0.1 & 79.6 & 61.3 & 79.6 & 0.9 \\
\hline \multirow[t]{3}{*}{6} & $9.4^{\mathrm{a}}$ & 53.3 & 0.07 & 74.1 & 50.0 & 32.7 & 60.0 \\
\hline & 0.9 & 57.0 & -1.1 & 51.1 & 47.8 & 35.3 & 58.9 \\
\hline & 0.5 & 61.5 & 0.1 & 56.6 & 42.5 & 29.7 & 53.2 \\
\hline \multirow[t]{3}{*}{7} & 0.5 & 52.9 & 0.7 & 40.4 & 40.2 & 34.0 & 38.0 \\
\hline & 0.7 & 55.1 & 0.8 & 44.9 & 43.7 & 37.0 & 48.6 \\
\hline & 0.2 & 61.2 & 1.5 & 48.7 & 41.1 & 35.0 & 47.3 \\
\hline \multirow[t]{3}{*}{8} & 0.6 & 73.1 & 0.1 & 77.3 & 50.7 & 74.4 & 57.7 \\
\hline & 0.7 & 70.8 & 0.0 & 84.0 & 50.4 & 75.3 & 64.3 \\
\hline & 0.5 & 73.3 & 0.0 & 73.8 & 48.6 & 69.6 & 51.5 \\
\hline \multirow[t]{3}{*}{9} & 0.6 & 62.3 & 1.4 & 81.1 & 50.5 & 0.6 & 62.0 \\
\hline & 0.5 & 63.5 & 1.3 & 77.0 & 57.2 & 0.5 & 50.5 \\
\hline & 0.3 & 70.3 & 1.4 & 73.4 & 0.5 & 70.8 & 53.2 \\
\hline \multirow[t]{3}{*}{10} & 0.0 & 61.9 & 0.0 & 48.9 & -1.0 & 51.1 & 31.5 \\
\hline & 0.0 & 63.7 & 0.4 & 62.4 & 0.0 & 34.1 & 54.2 \\
\hline & 0.4 & 60.4 & -1.2 & 73.7 & 0.1 & 35.7 & 56.6 \\
\hline
\end{tabular}

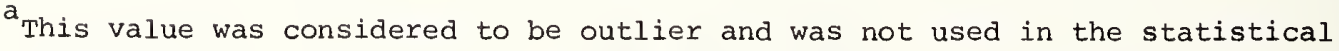
evaluation. 
Table 6. Pass and fail tabulation (smoldering combustion) by materials and laboratories

$\underline{L a b}$
$\underline{A}$
$\underline{\mathrm{C}}$
$\underline{E}$
$\underline{F}$
$\underline{G}$
B
$\underline{\mathrm{D}}$

1

$\mathbf{P}$

P

F

F

F

F

F

$2 \quad \mathrm{P}$

$P$

P

P

P

$P$

$F^{\star}$

F

$\mathbf{F}$

P

$F^{*}$

F

F

(3)

P

$\mathbf{F}$

$F *$

F

6

7

P

P

F

F

P

F

P

F*

P

P

1

7

9

9

10

10

* Of 3 tests, 1 or 2 are close to zero, and the other much above $15 \%$. 


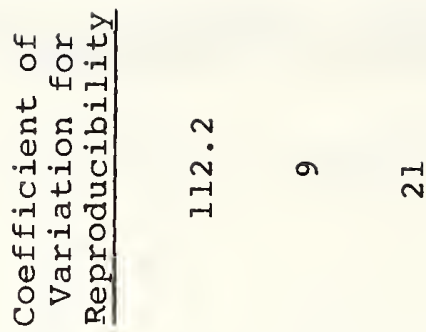

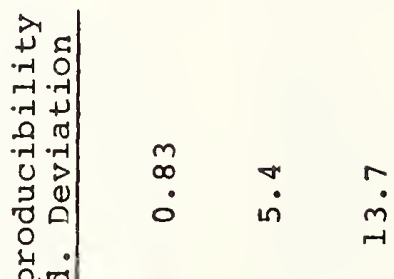

n

(1)

幽

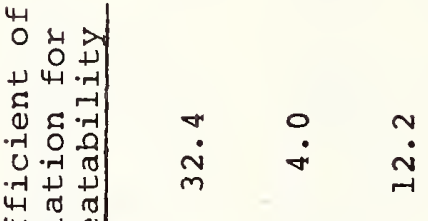

$4 .-10$

c) 4 2

0 .

崖.

4

0

(1)

整

Un

(1)

द म्न

in

- $्$

0

(1) 40

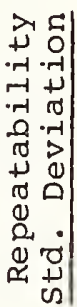

$\therefore$

苗

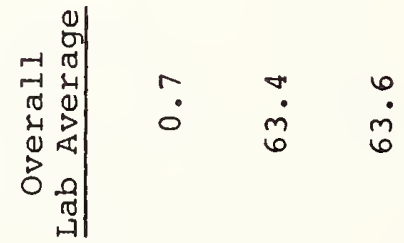

… 


\section{APPENDIX A}

PARTICIPANTS IN THE INTERLABORATORY FIRE TEST PROGRAM

Certified Testing Laboratories, Inc.

Dalton, Georgia 30720

Commercial Testing Company, Inc.

Dalton, Georgia 30720

Consumer Product Safety Commission

Engineering Laboratory

Bethesda, Maryland 20720

General Services Administration, FSS FML

Washington, D.C. 20405

Hauser Laboratories

Boulder, Colorado 80306

Independent Textile Testing Service, Inc.

Dalton, Georgia 30720

National Bureau of Standards

Center for Fire Research

washington, D.C. 20234

Oak Ridge National Laboratory

Operated by Union Carbide Corporation

Oak Ridge, Tennessee 37830

Ontario Research Foundation

Sheridan Park, Mississauga, Ontario

Canada L5K 1B3

Southwest Research Institute

San Antonio, Texas 78284

(Results received 8-28-78, too late for inclusion in the analysis.)

Underwriters' Laboratories, Inc.

Northbrook, Illinois 60062

(Results received 12-27-78, too late for inclusion in the analysis.)

United States Testing Company, Inc.

Hoboken, New Jersey 07030 

APPENDIX B

STATISTICAL METHODS

Nomenclature

$\left(\mathrm{CV}_{\mathrm{r}}\right)$

$\left(\mathrm{CV}_{\mathrm{R}}\right)$

$d_{i j}$

n

$\mathrm{p}$

$\mathbf{s}_{i j}$

$\left(s_{L}\right)_{j}$

$\left(s_{r}\right)_{j}$

$\left(s_{R}\right)_{j}$

${ }^{\left(s_{-}\right)}{ }_{j}$

$x_{i j}$

$\bar{x}_{j}$

Coefficient of variation for repeatability (within-laboratory)

Coefficient of variation for reproducibility (betweenlaboratories)

Cell deviations from average

Number of replicates per cell

Total number of laboratories

Cell standard deviation

Component of variance between laboratories

Pooled standard deviation for repeatability

Standard deviation for reproducibility

Intermediate variance quantity

Average for cell $(i, j)$ where $i$ represents the laboratory and $j$ the material

Average for one material for all laboratories 
Pooled Standard Deviation for Repeatability:

$$
\left(s_{r}\right)_{j}=\sqrt{\frac{1}{p} \Sigma_{i} s_{i j}^{2}}
$$

Equation (I) is applicable only when the number of replicates is the same for each laboratory for a given material. Where there are missing replicates in one or more laboratories use equation (la).

$$
\left(s_{r}\right)_{j}=\sqrt{\frac{\Sigma_{i}\left(n_{i j}-1\right) s_{i j}^{2}}{\Sigma_{i}\left(n_{i j}-1\right)}}
$$

Coefficient of Variation for Repeatability:

$$
\left(\mathrm{CV}_{r}\right)=100 \frac{\left(\mathrm{s}_{r}\right)_{j}}{\overline{\mathrm{x}}_{j}}
$$

Standard Deviation for Reproducibility:

First Calculate the "deviations from average" for each cell $(i, j)$ :

$$
d_{i j}=x_{i j}-\bar{x}_{j}
$$

Then calculate the intermediate variance quantity where:

$$
\left(s_{\bar{x}}\right)_{j}=\sqrt{\frac{\sum_{i}\left(d_{i j}^{2}\right)}{p-1}}
$$

Using $\left(s_{\bar{x}}\right)_{j}$ and $\left(s_{r}\right)_{j}$ calculate the "component of variance" between laboratories, where:

$$
\left(s_{L}\right)_{j}=\sqrt{\left(s_{\bar{x}}\right)_{j}^{2}-\frac{\left(s_{r}\right)_{j}^{2}}{n}}
$$

The variance of the total variability of a test results including both within and between laboratory variability is given by:

$$
\left(s_{R}\right)_{j}=\sqrt{\left(s_{r}\right)_{j}^{2}+\left(s_{L}\right)_{j}^{2}}
$$


Coefficient of Variation for Reproducibility: .

$$
\left(C V_{R}\right)_{j}=100 \frac{\left(s_{R}\right)_{j}}{\bar{x}_{j}}
$$

B- 3 

APPENDIX C

CELL AVERAGES AND STANDARD DEVIATIONS FOR CRITICAL RADIANT FLUX AND SMOLDERING COMBUSTION 


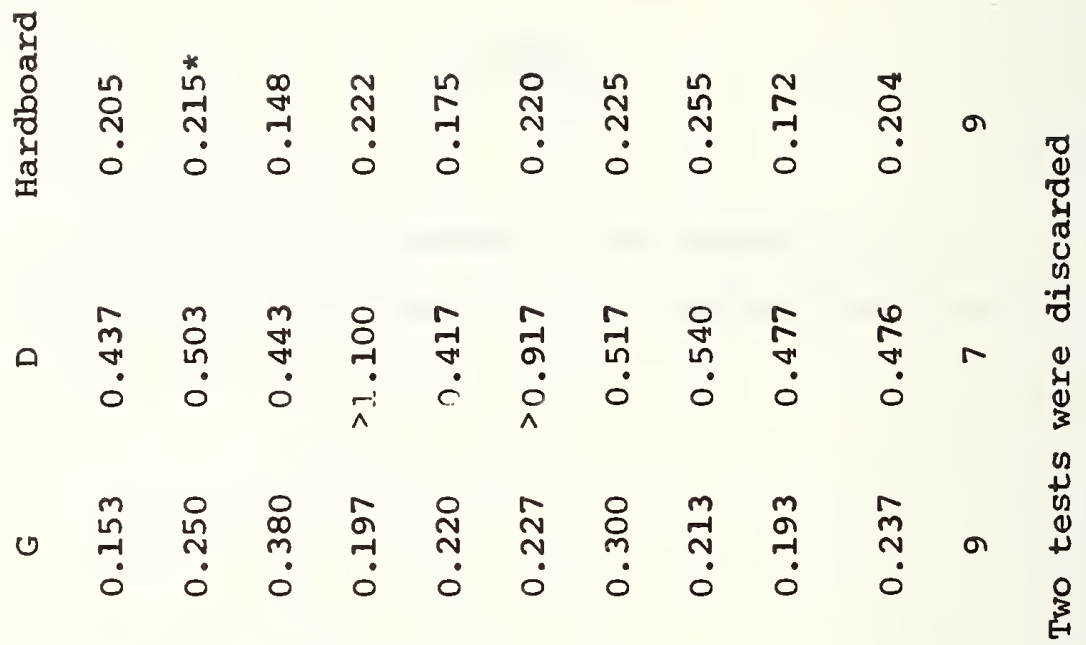

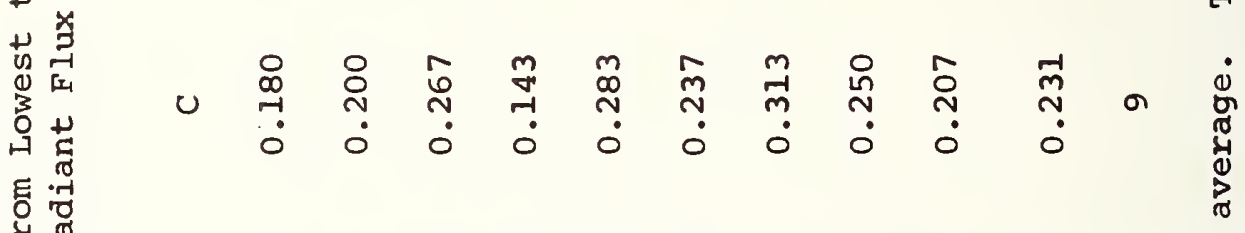

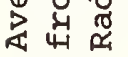
न 0 ن

范

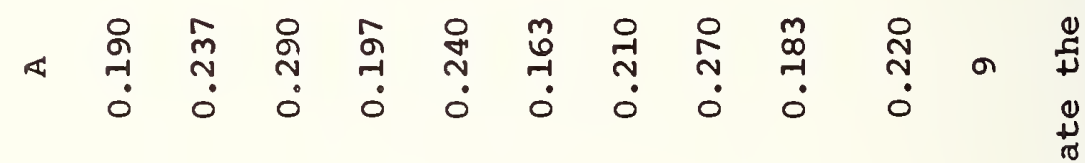

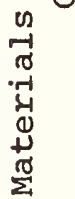

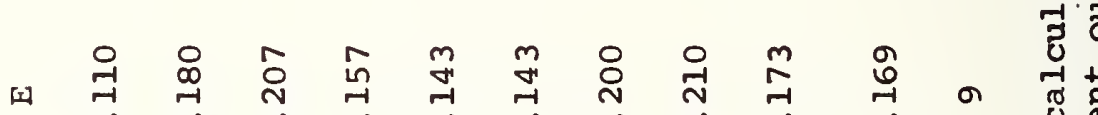

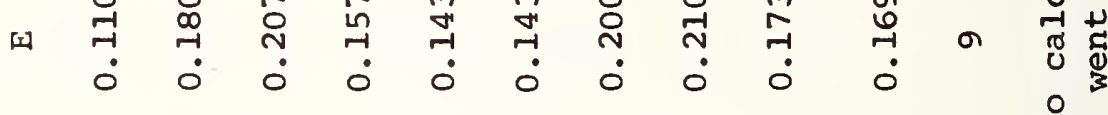

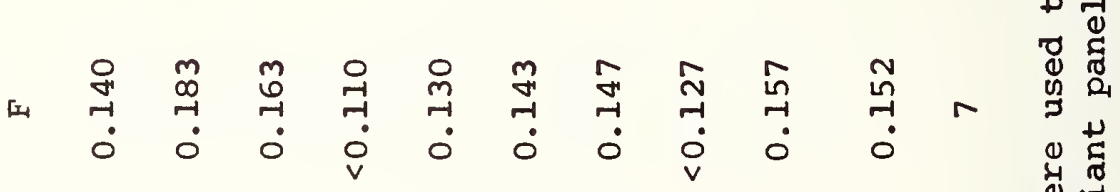

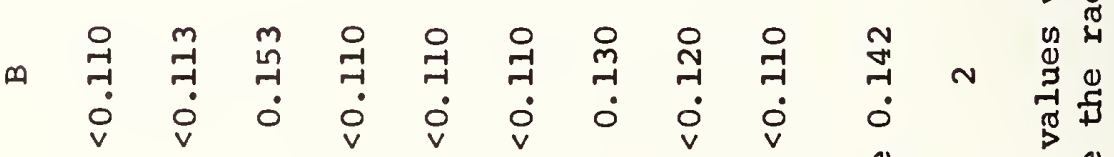

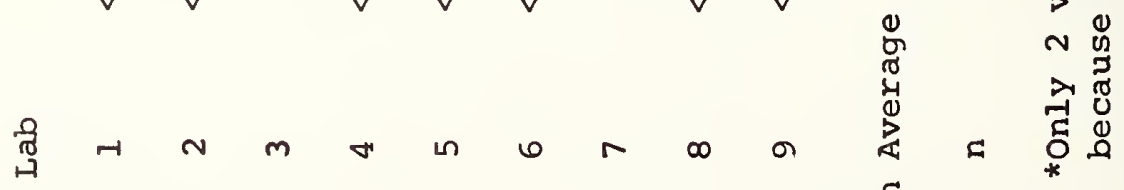
毫 


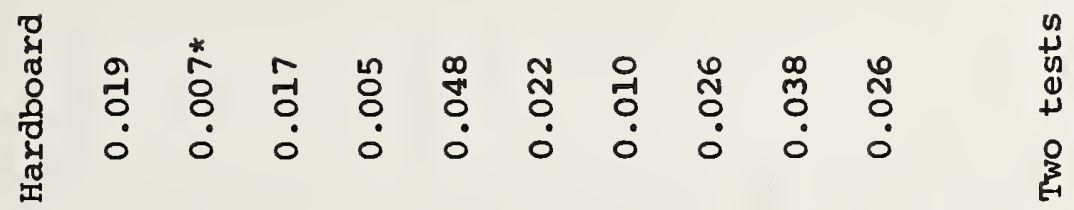

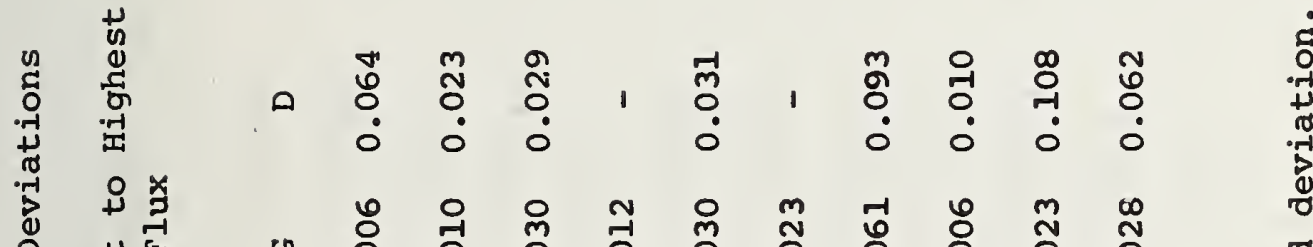
芴

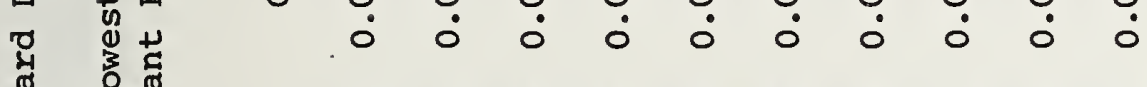

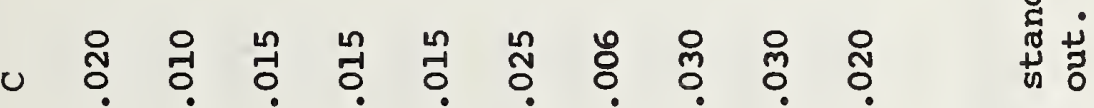

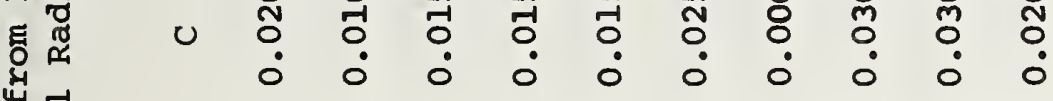

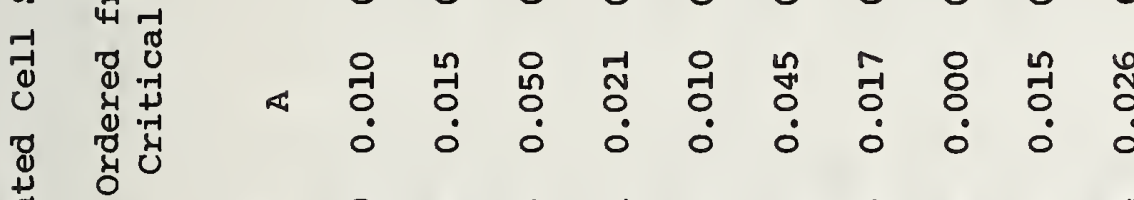

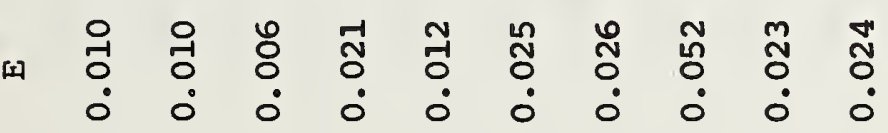

咅

न7

离

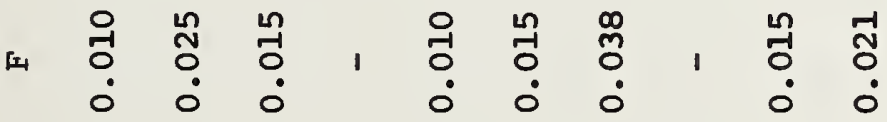

$\stackrel{4}{4}$

垔

త్

ठำ

$+\circ$

ช

(

ชู

(1)

औ

ט

ฐ

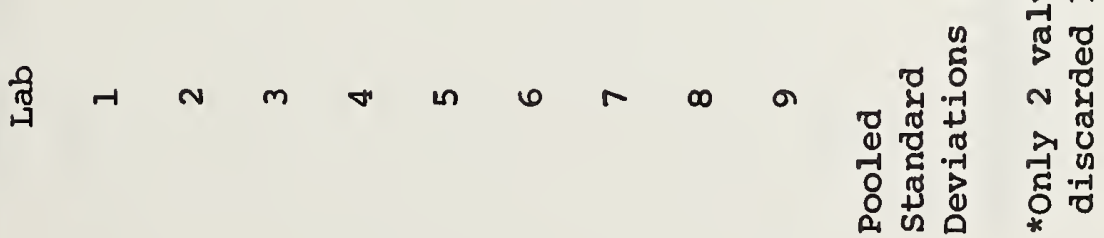


$n$
$n$
0
0
1

若著

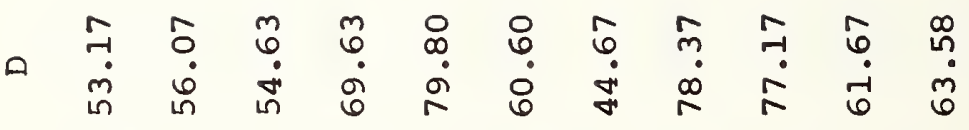

ญ ธิ

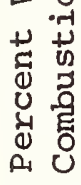

0
7
0
-1
0
0
0
$\Sigma$
$\Sigma$

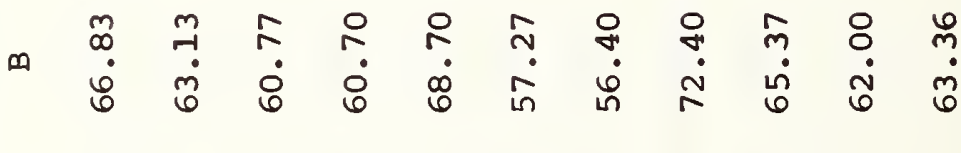

n

星

疍

of

엄

40

$>$

是

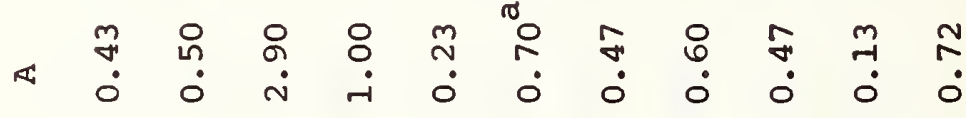

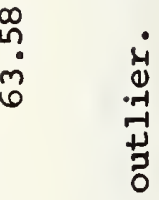

O

청

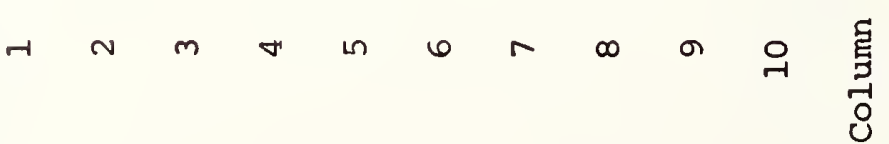

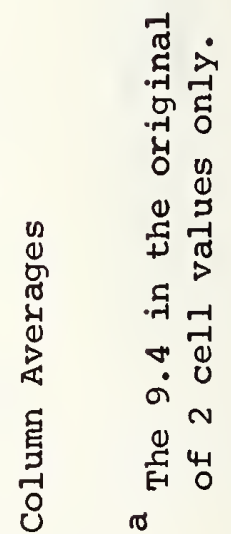




$$
\text { • }
$$

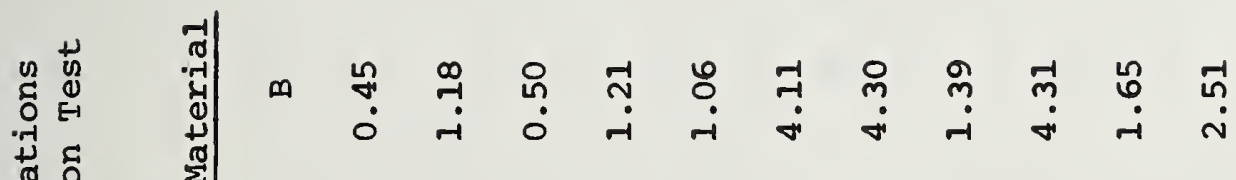
告虽

«

\%

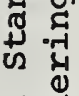

-

U

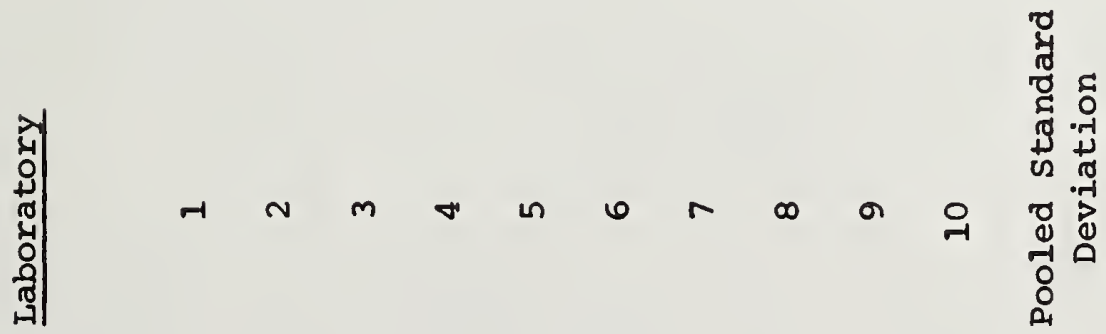




\begin{tabular}{|c|c|}
\hline $\begin{array}{c}\text { U.S. DEPT. OF COMM. } \\
\text { BIBLIOGRAPHIC DATA } \\
\text { SHEET }\end{array}$ & $\begin{array}{c}\text { 1. PUBLICATION OR REPORT NO. } \\
\text { NBSIR } 79-1588\end{array}$ \\
\hline
\end{tabular}

4. TITLE AND SUBTITLE

Interlaboratory Evaluation of the Attic Floor Radiant Panel Test and Smoldering Combustion Test for Cellulose Thermal Insulation

7. AUTHOR(S)
J. Randall Lawson
9. PERFORMING ORGANIZATION NAME AND AD
NATIONAL BUREAU OF STANDARDS
DEPARTMENT OF COMMERCE
WASHINGTON, DC 20234

12. SPONSORING ORGANIZATION NAME AND COMPLETE ADDRESS (Streot, City, stato, $z I P$ )

Consumer Product Safety Commission

Textile and Mechanical Engineering Group

Bethesda, Maryland 20202

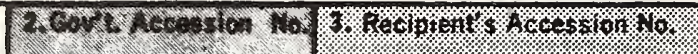

5. Publication Date

February 1979

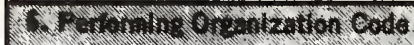

8. Performing Organ. Report No.

15. SUPPLEMENTARY NOTES

Document describes a computer program; SF-185, FIPS Software Summary, is attached.

16. ABSTRACT (A 200-word or less factual summary of most sigrificant information. If document includes a significant bibliography or iterature survey, mention it hero.) An interlaboratory test program was conducted to provide estimates of repeatability and reproducibility of fire tests for cellulose loose fill insulation. The test methods evaluated were for critical radiant flux, using the Attic Floor Radiant Panel, and for smoldering combustion; they were based on Federal Specification HH-I-515D. Seven commercially manufactured cellulose thermal insulations markete for residential use were evaluated by each procedure. An additional set of four replicate hardboard specimens were tested by each participant using the Attic Floor Radiant Panel. Nine laboratories conducted the Attic Floor Radiant Panel test, and ten conducted tests for smoldering combustion. The testing was conducted during the month of June 1978. The participating laboratories were surveyed prior to testing in order to ensure conformance to the critical details of the test apparatus and procedures.

The between-laboratory coefficient of variation for critical radiant flux ranged from 13 to 30 percent with an average for seven insulation materials of 21 percent. Estimated precision levels of repeatability and reproducibility for the Attic Floor Radiant Panel test when compared to other standard flame spread tests and materials are favorable. Data from the Smoldering Combustion test was evaluated on a pass/fail basis with agreement by nine of ten laboratories for six of the seven materials tested. Sever of ten laboratories also agreed on the seventh material.

Based on work of this study, there is reasonable assurance that results from different laboratories evaluating the same material for compliance with Federal specification $\mathrm{HH}-\mathrm{I}-575 \mathrm{D}$ will be consistent

17. KEY WORDS (six to twelve entries; alphabetical order; capitalize only the first letter of the first key word unless a proper name; separated by semicolons)

Attic floor radiant panel; cellulose thermal insulation; critical radiant flux; flame spread; test methods; smoldering combustion.

\begin{tabular}{|l|l|}
$\begin{array}{l}\text { 19. SECURITY CLASS } \\
\text { (THIS REPORT) }\end{array}$ & $\begin{array}{l}\text { 21. NO. OF } \\
\text { PRINTED PAGES } \\
\text { UNCLASSIFIED }\end{array}$ \\
\hline $\begin{array}{l}\text { 20. SECURITY CLASS } \\
\text { (THIS PAGE) } \\
\text { UNCLASSIFIED }\end{array}$ & 22. Price \\
\hline
\end{tabular}

